\title{
PBRM1 wt Allele
}

National Cancer Institute

\section{Source}

National Cancer Institute. PBRM1 wt Allele. NCI Thesaurus. Code C95439.

Human PBRM1 wild-type allele is located in the vicinity of 3p21 and is approximately 141 $\mathrm{kb}$ in length. This allele, which encodes protein polybromo-1, is involved in the regulation of both chromatin remodeling and transcription. 